Economica: Journal Of Economic And Economic Education Volume 10, Issue. 1, October 2021, pp 33-39

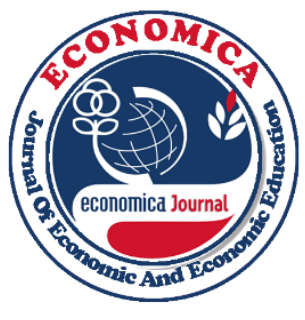

\title{
EVALUATION OF ADEQUACY OF BOS IN IMPROVING THE QUALITY OF EDUCATION
}

\author{
Ni Made Dea Ayu Theresia ${ }^{1)}$,Bambang Ismanto ${ }^{2)}$, Carolina Lita Permatasari ${ }^{3)}$ \\ ${ }^{1)}$ Economic Education Student, Universitas Kristen Satya Wacana, Indonesia \\ Email: 162017006@student.uksw.edu \\ ${ }^{2)}$ Economic Education Lecturer Universitas Kristen Satya Wacana, Indonesia \\ Email: bambang.ismanto@uksw.edu \\ ${ }^{2)}$ Economic Education Lecturer Universitas Kristen Satya Wacana, Indonesia \\ Email: carolina.permatasari@uksw.edu \\ Submitted: 2021.08.12 Reviewed: 202.10.05 Accepted:2021.10.30 \\ https://doi.org/10.22202/economica.2021.v10.i1.5041
}

\begin{abstract}
The problem that often becomes a problem is the high cost of education in an educational institution which results in public finances so that many children cannot carry out education, this will have an impact on decreasing the quality of education. This study aims to determine the evaluation of the adequacy of BOS in improving the quality of education, especially at SMA Negeri 2 Salatiga. This study uses descriptive research with a quantitative approach. The data acquisition was analyzed using quantitative descriptive methods. The population used is data related to the management of school operational assistance funds at SMA Negeri 2 Salatiga. The samples used in this study were principals, BOS treasurers, and teachers at SMA Negeri 2 Salatiga. The results of this study are 1) the receipt of BOS funds at SMA Negeri 2 Salatiga is given quarterly in one year 2) before the BOS funds are implemented the school makes an activity plan and school budget 3) on the use of BOS funds at SMA Negeri 2 Salatiga (2020) which is realized is the percentage of $97.36 \%$ and the unrealized amounted to $2.64 \%$ from the evaluation results that almost all of the realization of BOS funds were fulfilled
\end{abstract}

Jel Classification:

H43; G31, I2

Keywords: Evaluation, BOS Budgeting, Quality Of Education 


\section{INTRODUCTION}

Education in this era of globalization is an investment for the nation in improving the quality and competitiveness of human resources and plays a major role in realizing human beings who have good character. In developing their competencies optimally, every citizen has the right to obtain education and this is stated in the 1945 Constitution of the Republic of Indonesia Article 31 paragraph 1 (Lubis et al., 2019). In this case, the government is obliged to provide quality education services regardless of social status, religion, ethnicity, race, and gender so that citizens' rights to education are fulfilled. according to (Handoko et al., 2020) education is a requirement in the process of improving the quality of human resources through learning to compete in the world. The world of education continues to grow which requires the government to further improve the quality of existing education so that it can compete with other countries.

The problem that often becomes a problem is the high cost of education in an educational institution which results in public finances so that many children cannot carry out education, this will have an impact on decreasing the quality of education. The Indonesian government needs to develop a subsidy program to increase the level of basic education for all students, especially for the poor (Sulistyaningrum E, 2016). Various policies have been pursued by the Government to improve the quality of education. One of them allocates funds for education, namely the School Operational Assistance (BOS) program. This is following government regulation No. 48 of 2008 that education financing is the responsibility of the government, local government, and the community. In addition to the central government, local governments also play a role in the success of the BOS program.

Local government readiness determines the success of the BOS program (Saalino, 2019). This opinion is in line with the findings of the research entitled "Implementation of Operational Assistance Policy in Madrasah (Case Study of the Implementation School Operational Assistance Policy Management in Improving Madrasah Quality in East Java)". The results of the study confirm that the implementation of the School Operational Assistance policy in madrasas is carried out to improve access, quality, equity, and quality of madrasa education (Darmawan \& Kusbandrijo, 2019). The existence of this program received support and a positive response from the madrasa management.

School Operational Assistance (BOS) has been provided by the government to all public and private schools from Elementary School, Junior High School, and Senior High School / Vocational High School as one of the government's efforts to provide free education, to support 9-year compulsory education (Rubiyati \& Ismanto, 2020). Procurement of School Operational Assistance Fund aims to help reduce school operational costs, improve accessibility and quality of learning for students (Prastiwi et al., 2021). It is hoped that the BOS program will provide educational facilities by freeing fees for school operational financing. According to (Andrew Rosser, 2018) one way to improve quality is BOS. "School Operational Assistance (BOS) is used to measure improve the quality of Indonesia's education system". Several aspects that must be considered in improving quality include minimum material to achieve minimum graduate competencies at certain levels and types of education.

Several factors determine the success of the BOS program, one of which is the management of funds that can be managed properly and efficiently. According to Kaswandi (Silele, 2017) until now the problem that often occurs in the use of BOS funds is the lack of transparency in the use of these funds because some schools do not want their accountability reports to be known by the public. Previously, some literature that had reviewed the evaluation of operational assistance in schools (Sonhaji, 2020) concluded that the use of BOS funds for SD Negeri 1 Pulau Rimau was effective, namely if a percentage was paid for staff/GTT/PTT honorarium payments, $30 \%$ personnel, procurement of goods. and $25 \%$ services, $20 \%$ for 
learning and teaching activities, and $10 \%$ for student activities and school building maintenance. However, when compared with the results of research from (Bajari \& Nugraha, Agung, 2020) that the allocation of the amount of school operational assistance funds given to schools is unsatisfactory, the limited allocation causes it to only focus on important things. Furthermore (Setyoko et al., 2016) examined the effectiveness of the implementation of School Operational Assistance (BOS) with the title "Evaluation of School Operational Assistance by using CIPP Model in Indonesia Private Islamic Elementary School" concluded that there is still a need for regular socialization to all school stakeholders. This of course requires periodic evaluation of School Operational Assistance (BOS).

School operational assistance is a fund intended for educational activities to realize nine-year compulsory education (Yusmaridi et al., 2021). School operational assistance is believed to be an effective step for the community to complete the nine-year compulsory education and is considered to be able to reduce the dropout rate (Hadiyanto et al., 2019). SMA Negeri 2 Salatiga is one of the schools that receive school operational assistance (BOS) allowances from the government. Every year BOS is given to schools to support teaching and learning activities in schools.

Based on the background above and the data obtained about the importance of school operating assistance (BOS) in improving the quality of education and as the main source of support for support in schools, the author is cured to examine the "evaluation of the adequacy of the boss in improving the quality of education" by taking a case study in the country of SMA Negeri 2 SalatigaBased on the background above the role of the importance of school operating assistance (BOS) in improving the quality of education and as the main source of supporting funds at school, This research is similar to research by (Rubiyati \& Ismanto, 2020) regarding the evaluation of BOS evaluations carried out in schools whose novelty in this study is to look at the evaluation of the use of BOS funds seen from the percentage of use not from the acceptance process as in previous studies. This study aims to determine the evaluation of the adequacy of BOS in improving the quality of education, especially at SMA Negeri 2 Salatiga.

\section{METHODS}

In a previous study conducted by (Silele E, 2017) on Evaluation of School Operational Assistance (BOS) Management (Case Study at SD Inpres 4, Akediri Village, Jailolo District, West Halmahera Regency) where the research used qualitative methods. In this study, the researcher modifies the method with descriptive research where this method discusses a problem in detail by describing and describing a systematic, factual, and accurate situation about the facts, the nature of the relationship between the phenomena being punished so that a conclusion can be drawn for answer According to (Arikunto, 2019) quantitative research is research that uses a lot of numbers, starting from data collection, data interpretation, and display of these results are also manifested in numbers. In this study, the population in question is data related to the management of school operational assistance funds. In this study, the samples used were principals, treasurers, superiors, and teachers at SMA Negeri 2 Salatiga. The data analysis technique in this study uses descriptive data analysis through several data collection techniques, namely observation, interview documentation (Sugiyono, 2018). 


\section{RESULT AND DISCUSSION}

In planning for the management of school operational assistance funds at SMA Negeri 2 Salatiga, it begins with compiling and making an activity plan and school budget (RKAS). The preparation of activity plans and school budgets is based on the needs of the divisional work program. School activity plans and budgets are obligations that must be made by schools. At SMA Negeri 2 Salatiga, the team appointed to make the RKAS were the management, treasurer, principal, and also the school committee. The school's activity plan and budget must also refer to the school's vision and mission so that the activities expected by the school can be well planned. The following table shows a complete recap of the use of BOS funds for the period January - December 2020.

Table 1. Complete data on the use of BOS funds January - December 2020

\begin{tabular}{clc}
\hline No & \multicolumn{1}{c}{ Description } & $\begin{array}{c}\text { percentage of } \\
\text { use of BOS } \\
\text { fund }\end{array}$ \\
\hline 1 & Student Admission & $2,06 \%$ \\
2 & Library Development & $14,65 \%$ \\
3 & Learning and Extracurricular Activities & $21,45 \%$ \\
4 & Assessment/Learning Evaluation Activities & $10,26 \%$ \\
5 & School Activities Administration & $14,64 \%$ \\
6 & Professional Development of Teachers and Education Personnel & $2,40 \%$ \\
7 & Data Services and Services & $10,32 \%$ \\
8 & Maintenance of School Facilities and Infrastructure & $16,83 \%$ \\
9 & Purchase of Learning Multimedia Tools & $4,74 \%$ \\
10 & Organizing special job fairs, industrial work practices or domestic & \\
& fieldwork practices, job monitoring, teacher apprenticeships, and & \\
& first-party certification institution & \\
11 & Organizing skills competency test activities, expertise competency & \\
& certification, and competency tests for English language skills with & \\
& international standards and other foreign languages for the final class & \\
& of SMK and SMALB & \\
\hline Source $:$ SMA Negeri 2 Salatiga
\end{tabular}

In the first quarter, the percentage of the use of BOS funds at SMA Negeri 2 Salatiga was allocated for school needs. The use of BOS funds for library development is $0.04 \%$. BOS funds were also used for learning and extracurricular activities by $5.91 \%$. In the assessment/evaluation of learning activities, BOS funds were used at $2.99 \%$. Then in the administration of school activities the BOS funds used were $0.99 \%$. Professional development of teachers and education personnel by $0.1 \%$. Maintenance of school facilities and infrastructure which includes maintenance and also school maintenance and purchase of inventory is $4.46 \%$. In the first quarter, the total use of school operational assistance funds was $16.52 \%$.

In the second quarter, data on the percentage of the use of BOS funds were obtained as follows. New student acceptance is $2.06 \%$, for library development $14.61 \%$, learning and extracurricular activities are $6.06 \%$. In the assessment and evaluation of learning activities, the percentage of use of BOS funds is $6.08 \%$, in the professional development of teachers and education personnel by $0.02 \%$, the use of BOS funds for services and services is $5.57 \%$, 
maintenance of facilities and infrastructure in schools is $7.22 \%$ and the purchase of multimedia tools for learning is $4.74 \%$. In the second quarter, the total use of BOS funds was $51.83 \%$.

The receipt of BOS funds at SMA Negeri 2 Salatiga also reached the third quarter with the percentage of BOS funds used as follows. In learning assessment/evaluation activities, the percentage of BOS funds used is $9.48 \%$, learning assessment/evaluation activities are $1.19 \%$, school administration activities are $8.17 \%$. The use of BOS funds in activities for professional development of teachers and education personnel is $2.37 \%$, power and services are $2.64 \%$ and maintenance of school facilities and infrastructure is $5.15 \%$. With this, the percentage of use of BOS funds in the third quarter is $29.00 \%$

From the data that has been analyzed, it is found that the use of BOS funds in SMA Negeri 2 Salatiga has reached $97.36 \%$ while for the use of funds that cannot be realized by $2.64 \%$. The results of interviews that were obtained that the use of BOS funds was not used because the program could not run due to the Covid 19 pandemic so that there were still BOS funds that had not been realized. The highest use of BOS funds was found in the second quarter which is $51.83 \%$ because, in the second quarter, BOS funds were used for new students and also for purchasing multimedia learning tools. The use of BOS funds is also intended for students at school. With the existence of BOS programs, students no longer need to be charged any fees so that students only focus on learning. At SMA 2 Salatiga the BOS fund program provided to each student is 1,500,000 for one year. SMA Negeri 2 Salatiga greatly upholds the transparency of funds used can be seen from meetings held every year. Evaluation of the BOS Program at SMA Negeri 2 Salatiga that the funds obtained are sufficient to meet the needs and programs that will be carried out by the school. The existence of the BOS program has helped the school in buying tools and for school improvement activities.

This research is in line with research conducted by (Silele E, 2017) on the Evaluation of School Operational Assistance (BOS) Management (Case Study at SD Inpres 4, Akediri Village, Jailolo District, West Halmahera Regency). The difference in the results of this study in previous studies where the Boss Fund was not properly absorbed due to the wrong technical instructions for the use of the Boss Fund, while in this study it was caused by Covid - 19 Pandemic.

\section{CONCLUSION}

In this study, it was found that the BOS program at SMA Negeri 2 Salatiga has been implemented by $97.36 \%$ where almost all school programs can be implemented. The highest use of BOS funds occurred in the second quarter of 51.83\%. The percentage of use of BOS funds is mostly used for learning and extracurricular activities. The existence of a school operational assistance program greatly eases the burden on parents because they no longer need to think about the cost of their children's education at school. School operational assistance funds are different from previous research conducted by (Silele E, 2017) where the distribution of BOS Funds is only adjusted to school needs caused by technical instructions errors while in this study it was caused by Covid-19 pandemic. 


\section{REFERENCES}

Andrew Rosser, M. F. (2018). The political economy of teacher management reform in Indonesia. International Journal of Educational Development, 61, 72-81. https://scholar.google.co.id/citations?view_op=view_citation\&hl=en\&user=2VxUowQA AAAJ\&citation_for_view=2VxUowQAAAAJ:BwyfMAYsbu0C

Arikunto. (2019). Prosedur Penelitian: Suatu Pendekatan Praktek (Research Procedure: A Practice Approach). Rineka cipta.

Bajari, A. H., \& Nugraha, Agung, R. (2020). The Improvement Of Education Quality In Jayapura Through The Evaluation Of School Operational Assistance Funding Regulation. International Journal of Advanced Education and Research, 5(4), 73-76.

Darmawan, A., \& Kusbandrijo, B. (2019). Implementation of Operational Assistance Policy in Madrasah (Case Study of the Implementation School Operational Assistance Policy Management in Improving Madrasah Quality in East Java). Journal of Resources Development and Management, 42-56. https://doi.org/10.7176/jrdm/61-06

Hadiyanto, Famella, S., \& Wiyono, B. B. (2019). The challenge of school operational assistance management in elementary schools. International Journal of Innovation, Creativity, and Change, 5(5), 421-432.

Handoko, H., Rustiadi, T., \& Mukaromah, S. B. (2020). Implementation of the Use of School Operational Assistance (BOS) Funds in Fulfilling Middle School Sports Infrastructure Facilities in Ngadirejo District. Journal of Physical Education and Sports, 9(2), 108-113.

Lubis, S., Hutabarat, M., \& Nasution, M. R. (2019). Undang Undang Dasar 1945. 4(1), 1-12. https://doi.org/10.31227/osf.io/498dh

Prastiwi, N. T., Purpuniyanti, M., Ismanto, B., Waruwu, M., Kristen, U., Wacana, S., Kristen, U., \& Wacana, S. (2021). Kecukupan Anggaran BOS dalam Peningkatan Mutu Pendidikan pada Sekolah Dasar. 158-165.

Rubiyati, W. R., \& Ismanto, B. (2020). Evaluasi Program Bantuan Operasional Sekolah (BOS) di Sekolah Dasar. Jurnal Kependidikan: Jurnal Hasil Penelitian Dan Kajian Kepustakaan Di Bidang Pendidikan, Pengajaran Dan Pembelajaran, 6(2), 220. https://doi.org/10.33394/jk.v6i2.2614

Saalino, E. M. (2019). Effectiveness of School Operational Assistance Program Implementation at SD Inpres Dekai, Yahukimo. 3502-3517.

Setyoko, A., Tunas, B., \& Sunaryo, W. (2016). Evaluation of School Operational Assistance by using CIPP Model in Indonesia Private Islamic Elementary School. International Journal of Managerial Studies and Research, 4(3), 44-49. https://doi.org/10.20431/23490349.0403007

Silele E, S. H. \& P. R. . (2017). Evaluasi Pengelolaan Dana Bantuan Operasional Sekolah (BOS) (Studi Kasus Pada SD Inpres 4 Desa Akediri Kecamatan Jailolo Kabupaten Halmahera Barat) Evaluation Of Management Of Operational Funt Of Case Study In The SD Inpres 4 Akediri Village District Jail. Jurnal Emba: Jurnal Riset Ekonomi, Manajemen, Bisnis Dan Akuntansi, 5(2), 1626-1635.

Sonhaji, A. (2020). Metode Penelitian Kualitatif Dalam Pendidikan. Banjarmasin: Universitas Lambung Mangkurat, Program S2 Manajemen Pendidikan, 2003).

Sugiyono. (2018). Metode Penelitian Kombinasi (Mixed Methods). CV. Alfabeta. 
Sulistyaningrum, E. (2016). Impact Evaluation of the School Operational Assistance Program (Bos) Using the Matching Method. Journal of Indonesian Economy and Business, 31(1), 33. https://doi.org/10.22146/jieb.10319

Yusmaridi, M., Sunarti, V., Rusdinal, R., Gistituati, N., \& Juita, D. (2021). Low Implementation of "Bos" Funds for Junior High Schools in Padang City, Indonesia. European Journal of Education Studies, 8(6), 234-250. https://doi.org/10.46827/ejes.v8i6.3795 